\title{
ASSOCIATION BETWEEN THE CONCENTRATION OF PROTOZOA AND SURROGATES IN EFFLUENTS OF THE SLOW SAND FILTRATION FOR WATER TREATMENT
}

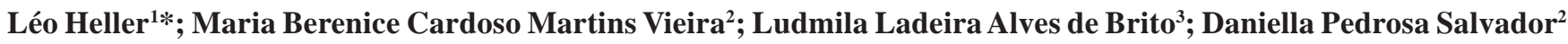 \\ ${ }^{1}$ Departamento de Engenharia Sanitária e Ambiental, Universidade Federal de Minas Gerais, Belo Horizonte, MG, Brasil; \\ ${ }^{2}$ Fundação Ezequiel Dias, Belo Horizonte, MG, Brasil, Instituto Brasileiro do Meio Ambiente e dos Recursos Naturais \\ Reniváveis, Brasília, DF, Brasil
}

Submitted: April 18, 2006; Returned to authors for corrections: June 08, 2006; Approved: March 18, 2007.

\begin{abstract}
Currently, a major challenge on producing high-quality drinking water is to monitor pathogens, such as Giardia, Cryptosporidium and enteric viruses. Due to limitations of the analytical methods available to detect pathogens in water, the research of surrogate indicators is an up-to-date subject. In view of these aspects, a pilot scale study was performed to evaluate the association between microbiological and physical indicators and the presence of Giardia spp and Cryptosporidium sp in the effluent of upflow and downflow slow sand filters. The results showed that efficient bacterial removal could indicate suitable protozoa removal. Although coliforms and Escherichia coli do not present the appropriate physiological profile for an "ideal" indicator, they are still good references for drinking water microbiological quality, specifically for slow sand filtration. The results also point out to the need of deeper researches about the use of anaerobic spores as routine indicator. Regarding the control of Cryptosporidium outbreaks, the expectation that a single indicator will satisfy all purposes is unreal. It may be more useful to know the advantages and disadvantages of several indicators, and integrate them appropriately.
\end{abstract}

Key words: Cryptosporidium, Giardia, slow sand filtration, surrogate, microbiological indicator

\section{INTRODUCTION}

Technicians and scientists involved with the drinking water issue have been following the significant changes in the water quality control and surveillance paradigms because of the concern with the potential presence of pathogens in water. It is clear that continuous optimization processes, based only on the current water turbidity monitoring practice, need to be revaluated $(5,26)$. This fact becomes more evident when the occurrence of outbreaks of waterborne diseases is associated with water that meets all regulatory requirements. The most famous example was the outbreak of cryptosporidiosis in Milwaukee (Wisconsin, USA), in 1993, when over 400,000 people were infected, and over 100 died $(10,20,21)$.

Physical and biological parameters may be used as performance indicators to evaluate the feasibility of the treatment processes regarding pathogen removal. The most used physical parameters are turbidity and particle count, while the most used biological parameters are mainly total coliforms, thermotolerant coliforms, E. coli, heterotrophic bacteria, aerobic spores, and anaerobic spores. Other parameters have been suggested as well, such as pollen, algae, and fungus spores (16).

Currently, a major challenge on producing high-quality drinking water is to monitor pathogens, such as Giardia, Cryptosporidium and enteric viruses. The sampling and analytical methods available to detect Giardia cysts and Cryptosporidium oocysts are neither sensitive nor precise (6).

The need for a surrogate indicator has become more and more urgent. Any good indicator should be abundant in water, conservative, and treatment resistant. Furthermore, it should be easily, quickly, and cheaply detected and quantified. Several

*Corresponding Author. Mailing address: Departamento de Engenharia Sanitária e Ambiental, UFMG. Av. Contorno, 842/715 - 30.110-060. Belo Horizonte, Brasil. Tel.: (55) 3238-1958. E-mail: heller@desa.ufmg.br 
characteristics of the Cryptosporidium make the research on an indicator for it somehow challenging: it has multiple hosts (humans, calves, sheep, etc), it can survive in the environment for a long time, and it is resistant to usual disinfection processes.

A clear gap on the literature about the best surrogates for protozoa in slow sand filters effluent is evident. While some studies have been performed to evaluate conventional water treatment techniques, there are no specific studies about slow sand filtration, which is a promising process due to its operational simplicity and potential effectiveness in the removal of pathogens (7).

A research carried out at the University of Colorado, USA, from 1995 to 1998, investigated a broad range of microorganisms in order to evaluate whether they could be used as pathogen removal indicators in water filtration process. The results pointed out that some bacteria, bacteriophages, and algae could represent Giardia and Cryptosporidium in such treatment process. The study also showed that the selection of one reliable indicator amongst so many uncertainties in the analytical pathogen identification methods would be a difficult task (13).

Swertfeger et al. (23) have also evaluated endospores, particle count, and turbidity as performance indicators in the removal of protozoa from artificially-contaminated water filtered in different filter media. The removal of endospores was slightly conservative compared with that of oocysts under both winter and summer conditions. Turbidity and particle number removal was lower than oocysts removal. Aboytes et al. (1), however, investigating 82 conventional (rapid) filters, found no differences in water quality (turbidity and microbial indicators) between sites with and without infectious oocysts in filtered waters.

Nieminski et al. (16) evaluated several microorganisms and physical parameters as candidates for pathogen surrogate, especially to be used as a tool to optimize treatment and to predict the occurrence of pathogens in drinking-water. A matrix has been developed to report the water quality and the different treatment processes in 23 treatment plants, and one non-filtered water supply. The following bacteria and bacteriophages have been selected as candidates for microbiological surrogates for Giardia, Cryptosporidium, and enteric viruses: total aerobic spores, including Bacillus subtilis spores; Micrococcus luteus, which were later replaced by anaerobic bacteria spores, including Clostridium perfringens; counts of heterotrophic bacteria; total and fecal coliform bacteria; somatic coliphages and F-RNA coliphages. Turbidity and particle count have been proposed for non-microbial measurements. The conclusions of the study inferred that a single measurement of an indicator is not sufficient to evaluate the treatment, but the combination of a number of indicators - physical and biological - in the filtered water should be taken instead, in order to decide whether a specific level of treatment is suitable.
Several factors influence the presence of both parasites and microbiological surrogates in water, as the temporal and spatial heterogeneity, bringing increase complexity for the identification of ideal surrogates. Gale et al. (11), in this aspect, showed the effect of water treatment on the spatial heterogeneity, due to the likely increase of clustering after chemical treatment. Influent concentration, type of filter media and coagulant dose are other factors associated with the removal of microorganisms in rapid filters (14).

In view of this context and these findings, a pilot scale study was performed to evaluate the association between microbiological indicators (anaerobic bacteria spores, including Clostridium perfringens; aerobic bacteria spores, including Bacillus subtilis; total coliforms, including Escherichia coli), turbidity, and the presence of Giardia spp and Cryptosporidium sp protozoa in the effluent of upflow and downflow slow sand filters.

\section{MATERIALAND METHODS}

\section{Experimental apparatus}

The experimental investigation consisted in operating the pilot plant of slow sand filters at different filtration rates and flow directions. The experiment was performed in the pilot units of the Pilot-Plant Laboratory of the Department of Sanitary and Environmental Engineering at the UFMG, in partnership with the Food and Water Microbiology Laboratory of the Fundação Ezequiel Dias de Minas Gerais (FUNED).

Fig. 1 depicts the setup. Each filter - one downflow and another upflow - consisted of two overlapped acrylic pipes $(0.20 \mathrm{~m}$ diameter, $1.50 \mathrm{~m}$ high). A perforated plate was fastened to the lower part of each filter to support the granular media, located at $0.10 \mathrm{~m}$ from the base. Water inlet in the downflow slow sand filter was located $0.30 \mathrm{~m}$ below the upper edge of the filter (1.45 $\mathrm{m}$ above the filter medium), and the water outlet was just below the perforated plate, in an inverted " $U$ " shape that maintained a minimum $0.45 \mathrm{~m}$ water level above the filter medium. In the upflow slow sand filter, the inlet was located $0.10 \mathrm{~m}$ above the lower base of the filter, and the outlet was located at $0.30 \mathrm{~m}$ below the upper edge ( $1.45 \mathrm{~m}$ above the filter medium). The medium in both filters consisted of sand $(0.75 \mathrm{~m}$ thick, effective dimension of $0.25 \mathrm{~mm}$, uniformity coefficient of 2.40 , minimum diameter of $0.084 \mathrm{~mm}$, and maximum diameter of $1.00 \mathrm{~mm}$ ). The supporting layer consisted of three gravel layers, in which the grain size ranged from 1.20 to $19.10 \mathrm{~mm}$.

\section{Experimental Water}

Water taken from the public network was dechlorinated, through activated carbon filters, and then mixed with bentonite $(14 \mathrm{~g} / 400 \mathrm{~L})$, to generate turbidity; Paraguay tea infusion (160 $\mathrm{ml} / 400 \mathrm{~L})$, to produce color; sulphuric acid $1 \mathrm{~N}(100 \mathrm{~mL} / 400 \mathrm{~L})$, to adjust the $\mathrm{pH}$; an aliquot of sewage $(40 \mathrm{~mL} / 400 \mathrm{~L})$, to provide 


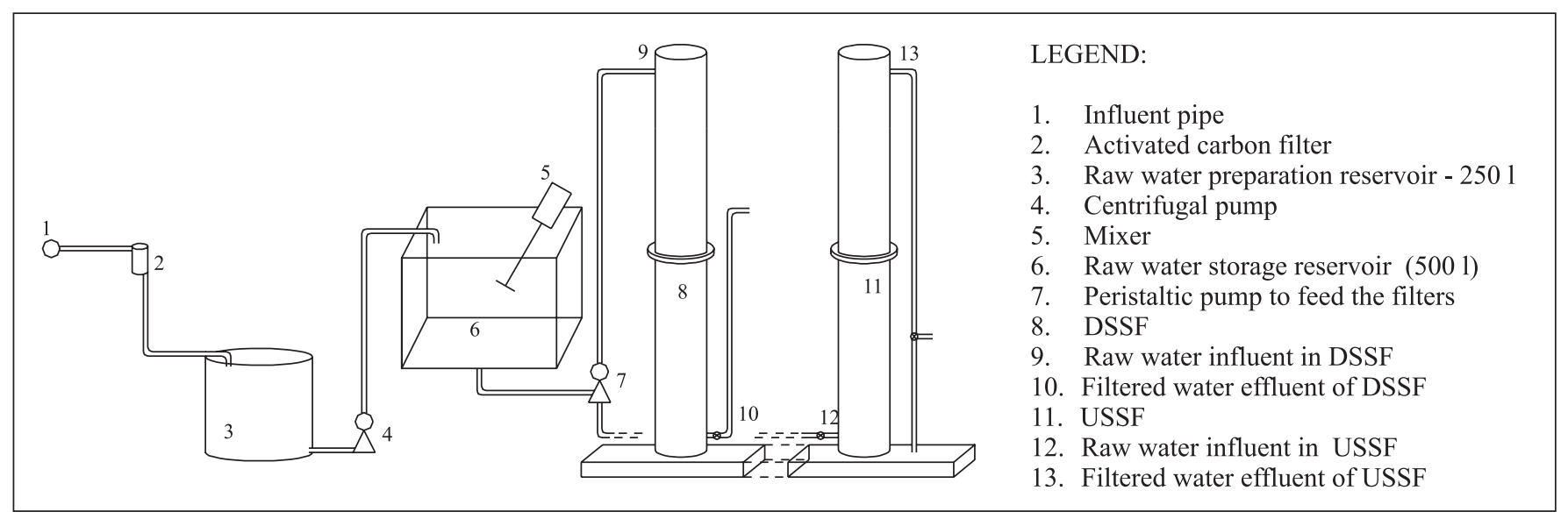

Figure 1 Pilot plant scheme.

the microorganisms to be analyzed (total coliforms, Escherichia coli, Clostridium perfringens and anaerobic bacteria spores, Bacillus subtilis and aerobic bacteria spores, Giardia cysts); and Cryptosporidium oocysts, that were produced in a newlyborn calf $\left(55 \mu \mathrm{L}\right.$ of stock solution with $7.8 \times 10^{5}$ oocysts $/ \mathrm{mL}$ in 400L).

The resulting physical and microbiological characteristics of the experimental water, which is suitable to be treated in slow filtration process, were: turbidity: $15+/-5 \mathrm{UT}$; true color: $15+/-$ $5 \mathrm{UC}$; pH: 6.5 - 7.5; total coliform: $10^{5}-10^{6} \mathrm{MPN} / 100 \mathrm{~mL}$; Escherichia coli: $10^{3}-10^{4} \mathrm{MPN} / 100 \mathrm{~mL}$; Clostridium perfringens and anaerobic bacteria spores: $10^{1}-10^{2} \mathrm{CFU} / 100 \mathrm{~mL}$; Bacillus subtilis and aerobic bacteria spores: $10^{4}-10^{5} \mathrm{CFU} / 100 \mathrm{~mL}$; Cryptosporidium: $10^{1}-10^{2}$ oocysts/L; Giardia: $10^{0}-10^{1}$ cysts/L.

The water was prepared at a batch process, in a reservoir of $500 \mathrm{~L}$, such as each volume was sufficient to feed the pilot filter during approximately 0.5 or 1.0 day, for the high-rate or the lowrate, respectively. This residence time was considered low enough to not alter the concentration of the added microorganisms.

\section{Sample collection and analysis planning}

The slow sand filters were tested operating in two flow directions (upflow and downflow) at two different filtration rates: low-rate $\left(3 \mathrm{~m}^{3} / \mathrm{m}^{2} \cdot \mathrm{d}\right)$, and high-rate $\left(6 \mathrm{~m}^{3} / \mathrm{m}^{2} \cdot \mathrm{d}\right)$. For each of the four combinations between flow directions and rates, two sequential runs were operated in the same filter, in order to assure duplets.

\section{Sampling}

The water samples were collected upstream of the filters and from the filtered effluent.

The samples were collected each 24 hours on the first three days, widening to each 48 hours, and then each 72 hours, for a maximum period of 30 days of run. This scheme resulted in different $\mathrm{N}$ for each filter run, regarding the flow direction and the filtration rate, as show in Tables 3 and 4 . For the bacteriological analyses, $500 \mathrm{~mL}$ of sample were aseptically collected into sterilized flasks and, for the analyses of protozoa, $10 \mathrm{~L}$ volumes were collected in disinfected containers.

\section{Physical-chemical analysis}

Turbidity was monitored daily, and measured according to method 2130B of the $20^{\text {th }} \mathrm{Ed}$. of the Standard Methods for the Examination of Water and Wastewater (2), using a Hach turbidimeter model 2100AN.

\section{Microbiological analyses}

The methods for bacteriological analysis were: total coliforms and Escherichia coli: Standard Methods 92231 . Colilert ${ }^{\circledR}$; anaerobic bacteria spores and Clostridium perfringens: Fout et al. (9) - EPA/ICR; aerobic bacteria spores and Bacillus subtilis: Rice et al. ${ }^{18}$, modified by Nieminski et al. (16); Giardia spp and Cryptosporidium sp: Vesey et al. (25).

Cryptosporidium sp and Giardia spp, microorganisms that were more emphasized in this study, were concentrated through the calcium carbonate flocculation method developed by Vesey et al. (25). Cysts and oocysts from concentrated samples were identified using the direct immunofluorescence technique in a Merifluor C/G kit (Meridian Diagnostics, Inc., Cat. \# 250050).

\section{Data analyses}

Statistical analyses were performed using both Microsoft Excel for Windows and Statistica 5.0 (Statsoft Inc.), according to the specificities of each package, and to the demands of the study. The Statistica 5.0 was used in descriptive statistics and to calculate correlations. Since the data obtained did not fit in a normal distribution, the correlations among the counts were evaluated by using the Spearman correlation, in order to 
compare classification orders between two parameters. This non-parametric test measures the association power between pairs of variables, without specifying which variable is dependent or independent, and assumes that the errors in the distribution of the compared data sets are the same (8).

\section{RESULTS}

Tables 1 and 2 present, for each parameter, the range and the median values in the effluent, and the removal efficiency, in the slow sand filters (upflow and downflow; both filtration rates). The results show a likely growing mechanism in the filters for aerobic spores - and Bacillus subtilis in some cases - and removal efficiency consistently higher than $90 \%$ for turbidity, Clostridium perfringens, Cryptosporidium and Giardia.

Spearman coefficients were calculated in order to evaluate the correlation between Cryptosporidium and all the studied microorganisms and between Cryptosporidium and the turbidity values as well. Table 3 depicts the correlations obtained from the effluent of the downflow slow sand filter (DSSF), upflow slow sand filter (USSF) and the integration of the values of both filters.

For the DSSF, the correlation between Cryptosporidium and total coliform showed the highest $r_{S}$, even though the best correlation was expected to be between Cryptosporidium and Giardia. The coefficients correlating Cryptosporidium and total coliforms, Giardia, E. coli, and anaerobic spores laid in a range varying from 0.4607 to 0.6640 , which is considered moderate ${ }^{22}$.

The correlations between Cryptosporidium and the several indicators in the experiment on the upflow slow sand filter (USSF), similarly to what occurred in the DSSF, showed no significant correlation between Cryptosporidium and turbidity, B. subtilis, $C$. perfringens, and aerobic spores, at a significance level of $5 \%$. Another similarity observed in both the DSSF and the USSF was the moderate range of the correlation coefficient values ( 0.3926 to 0.6724$)$ found for the same parameters: anaerobic spores, total coliforms, E. coli, and Giardia. However, it is relevant that, for the USSF, the best correlation coefficient was that between Cryptosporidium and Giardia, and not between Cryptosporidium and total coliforms as found for the DSSF.

For an overall verification of the association between Cryptosporidium and its potential indicators, the Spearman correlations were calculated using data from the experiments with both downflow and upflow filters, in order to control for the effect of small sample sizes, as relation between parameters is vulnerable to the random variation that might exist in the natural distribution of organisms in a sample (24).

This last analysis shows similarity in the results, as previously observed. The overall analysis of the results demonstrates no correlation between Cryptosporidium and $B$. subtilis, C.perfringens, turbidity and aerobic spores, at a significance level of 5\%. Moderate correlations were observed between Cryptosporidium and anaerobic spores, total coliforms, and $E$. coli. The best correlation coefficient was found between Cryptosporidium and Giardia, which was already expected due to the common characteristics between them.

The Spearman coefficients were also calculated for the association between Giardia and the microbiological indicators, and between Giardia and turbidity as well. The results obtained from the DSSF, USSF and both are presented in Table 4.

By analyzing the results for DSSF, it can be observed that Giardia had a single significant correlation (at $5 \%$ of significance level), with Cryptosporidium. For the USSF, Giardia did not correlate with turbidity, and with the microbial parameters, $B$. subtilis and $C$. perfringens. The best correlation coefficient was that with Cryptosporidium, somehow predictable. The anaerobic bacteria spores presented a correlation coefficient with Giardia similar to that with Cryptosporidium. An unforeseen significant reverse-correlation was found between Giardia and aerobic spores.

By increasing the sample size and performing a joint analysis for the data set from the two filters, new correlations were calculated. The results of the overall analysis kept a similarity with those of the USSF. Giardia presented no significant correlation with the same parameters: turbidity, C. perfringens, and $B$. subtilis. Excluding Cryptosporidium, the best correlation was that with the anaerobic spores. The correlations with the total coliforms and $E$. coli were similar to those with Cryptosporidium, although less strong. Differently from what was observed for Cryptosporidium, a poor reverse correlation with aerobic spores was found.

\section{DISCUSSION}

By evaluating the time evolution of the indicators and comparing the concentration of microorganisms with that of protozoa, irregular behaviors were observed, characterized by the presence of peaks and by a tendency to stabilization during the second filter run, with results of zeros prevailing in the effluents for the most part of the microorganisms.

An explanation for such evidence would be the lack of microbiological maturity of the filter medium during the first run and the presence of such maturity in the second run, supporting the hypothesis that the biological maturity of the filter medium is a very important variable in the microbial removal process in slow sand filtration. During the first run, the sand in the filter medium was clean - first usage sand. There was growth of microorganisms neither among the sand grains nor on the surface of the filter layer. The condition of maturity in the filter medium is developed after a filtration routine that varies from days to months, depending on the conditions of the influent water (4).

This study shows that the best correlations found for Cryptosporidium oocysts were those with the traditional indicators, $E$. coli $(\mathrm{r}=0.54, \mathrm{p}=0.000)$ and total coliform $(\mathrm{r}=0.51$, 


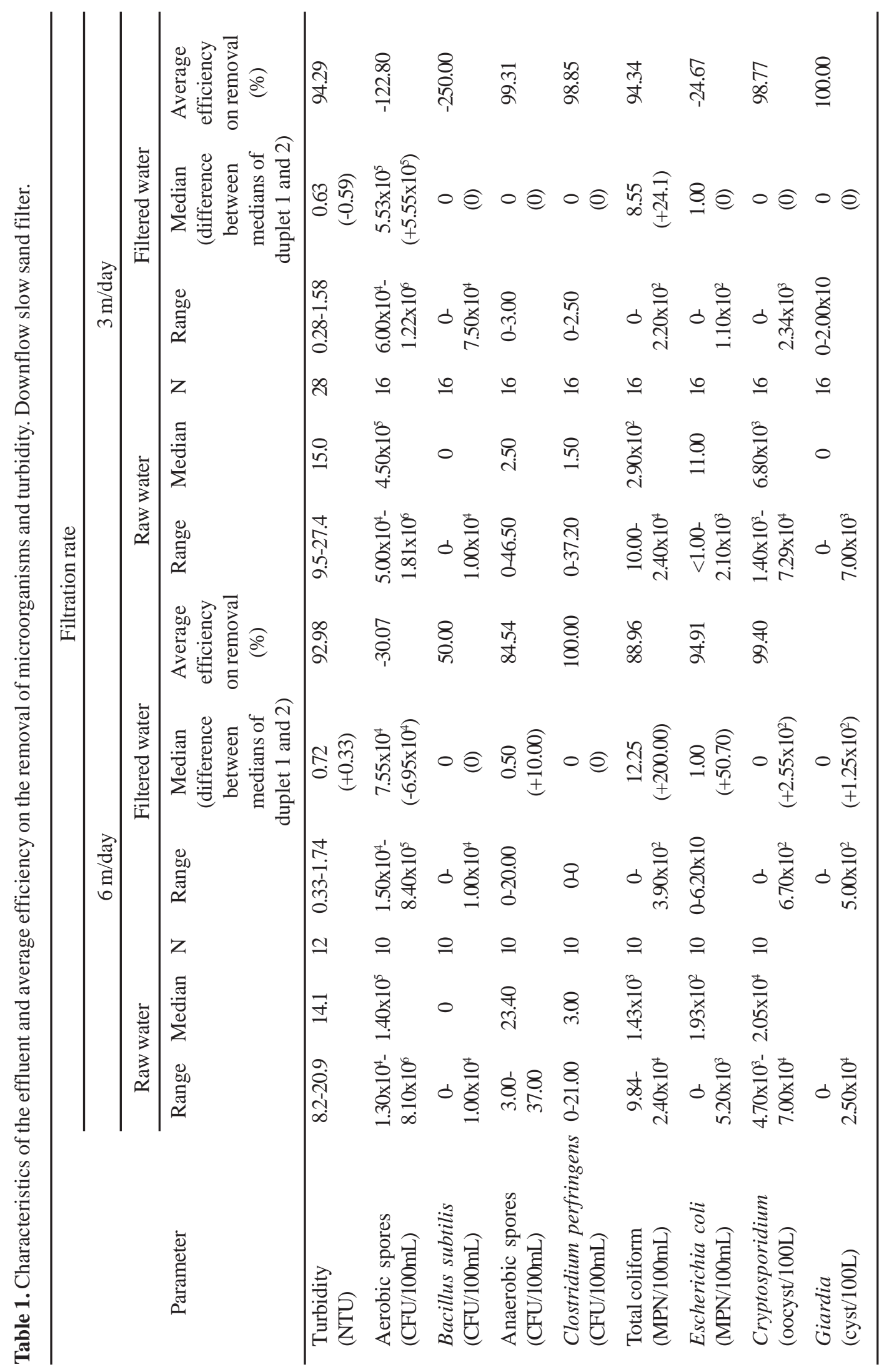




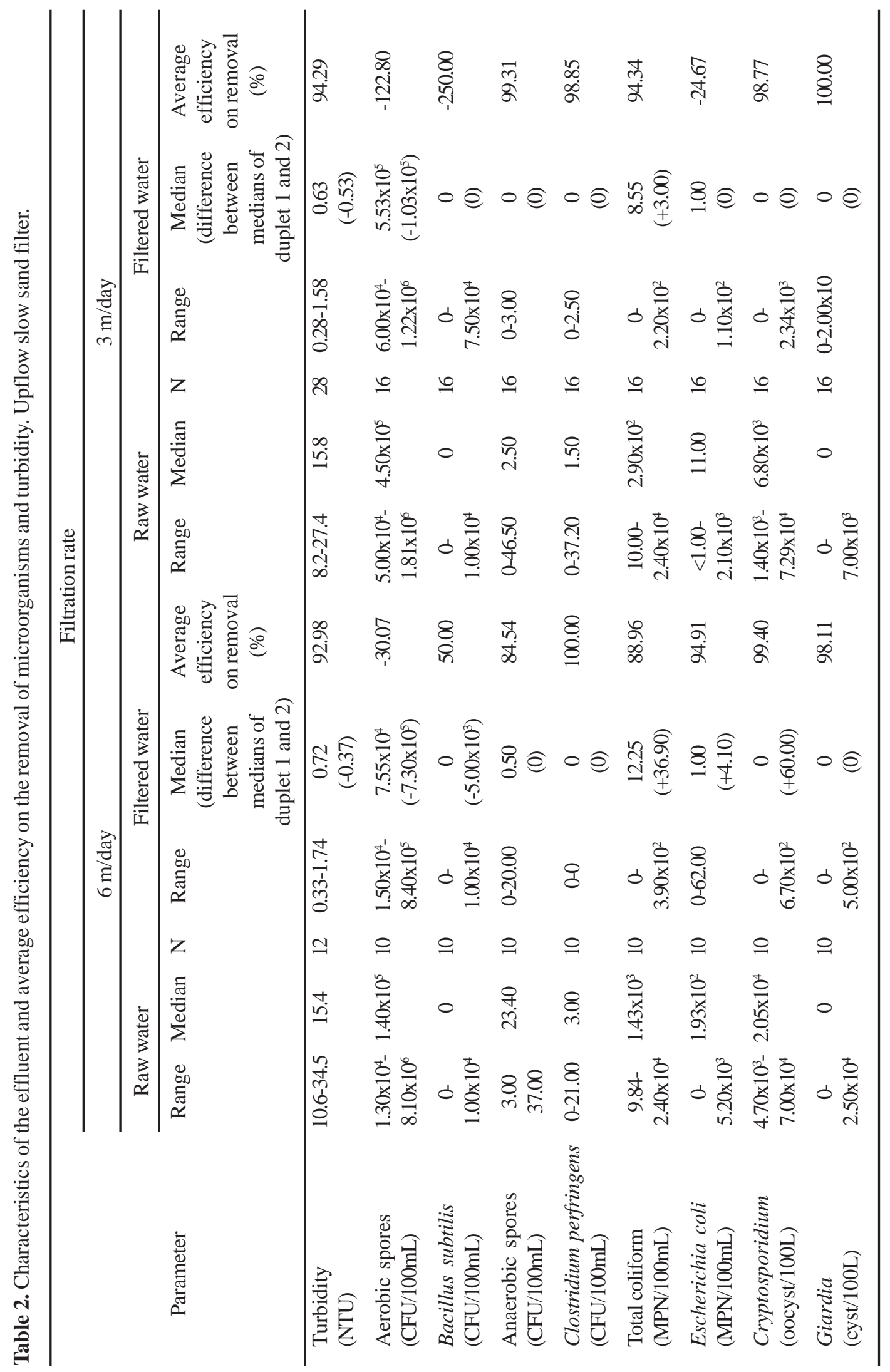


Table 3. Spearman correlations between Cryptosporidium and surrogates.

\begin{tabular}{|c|c|c|c|c|c|c|c|c|c|}
\hline Parameters & \multicolumn{3}{|c|}{$\begin{array}{c}\text { downflow slow } \\
\text { sand filter (DSSF) }\end{array}$} & \multicolumn{3}{|c|}{$\begin{array}{c}\text { upflow slow } \\
\text { sand filter(USSF) }\end{array}$} & \multicolumn{3}{|c|}{$\begin{array}{l}\text { downflow (DSSF) } \\
+ \text { upflow (USSF) } \\
\text { slow sand filters }\end{array}$} \\
\hline Cryptosporidium \& Turbidity & 26 & 0.2525 & 0.213406 & 48 & 0.0351 & 0.812817 & 74 & 0.1431 & 0.223997 \\
\hline Cryptosporidium \& Aerobic spores & 26 & -0.0945 & 0.646165 & 48 & -0.2053 & 0.161474 & 74 & -0.1544 & 0.189135 \\
\hline Cryptosporidium \& Clostridium perfringens & 26 & 0.2283 & 0.261913 & 48 & 0.1001 & 0.498662 & 74 & 0.1332 & 0.257940 \\
\hline Cryptosporidium \& Total coliforms & 26 & 0.6640 & $0.000217 *$ & 48 & 0.4081 & $0.003985^{*}$ & 74 & 0.5052 & $0.000004 *$ \\
\hline Cryptosporidium \& Escherichia coli & 26 & 0.5198 & $0.006494 *$ & 48 & 0.5275 & $0.000117 *$ & 74 & 0.5378 & $0.000001 *$ \\
\hline Cryptosporidium \& Giardia & 26 & 0.5990 & $0.001223 *$ & 48 & 0.6724 & $0.000000 *$ & 74 & 0.6442 & $0.000000 *$ \\
\hline
\end{tabular}

$* \mathrm{p}<0.05$.

Table 4. Spearman correlations between Giardia and surrogates.

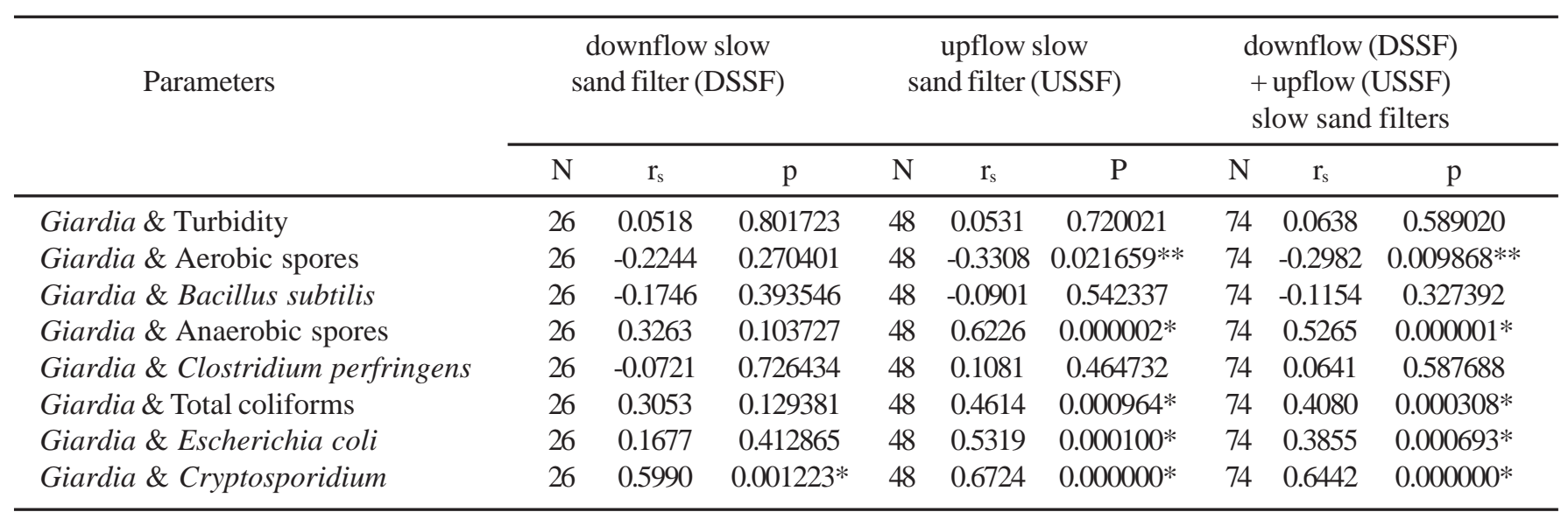

$* \mathrm{p}<0.05) ; *$ p $<0,05$ (relação inversa).

$p=0.000)$, besides anaerobic spores $(r=0.44, p=0.000)$. Similar results were found for both upflow and downflow slow sand filters.

The order inverted when Giardia cysts were present. The best correlation was that with anaerobic spores $(\mathrm{r}=0.53, \mathrm{p}=$ $0.000)$, followed by that with total coliform $(\mathrm{r}=0.41, \mathrm{p}=0.000)$ and with $E$. coli $(\mathrm{r}=0.39, \mathrm{p}=0.000)$. However, it is worthy to mention that in the downflow filter the only significant correlation was that with Cryptosporidium. In the upflow filter, the correlation with the aerobic spores was negative, that is, reverse.

The results show congruence but also differences when compared to what have been reported in the literature.

Aiming at finding more suitable indicators for contamination from viruses and protozoa in supply waters, Payment and Franco (17) analyzed large volumes of water samples from treatment facilities. They found out that, in river waters, the density of $C$. perfringens was the only parameter that had a significant correlation with the presence of Giardia cysts $(\mathrm{r}=0.76, \mathrm{p}=$ $0.001)$ and Cryptosporidium oocysts $(\mathrm{r}=0.65, \mathrm{p}=0.002)$. In filtered waters, somatic coliphages and $C$. perfringens had a significant correlation with Cryptosporidium oocysts, but not with Giardia cysts.

Nieminski et al. (16) observed no relation between the measurements of Giardia and Cryptosporidium and the microbial indicators tested in treated water. The pathogens and the indicators had low occurrence in filtered waters. Among the organisms candidate for indicators, only aerobic spores and heterotrophic bacteria were detected in $84 \%$ and $53 \%$ of the filtered water samples, respectively. Heterotrophic bacteria growth was detected in conventional treatment facilities, as 
well as in facilities treating water by direct filtration, and even in facilities in which the treatment process was disinfection only. Such characteristic prevents this parameter from being used as a performance indicator of water treatment. It is worth of mention that the authors analyzed the data by using linear correlations, reporting that they could have used non-parametric methods or neural networks to exploit the relations between these data, but they took into consideration that no statistical technique could compensate the poor analytical precision of determining the concentration of pathogens in the filtered water samples.

Gale e Stanfield (11) also found, in pilot studies, a high number of Bacillus subtilis var. niger spores in treated water 27 hours after its addition to the raw water, which suggests that large variations may occur in the number of spores in treated waters, even in very short periods of time. The varied number of spores could simply reflect either the spread or sporulation of spore-forming bacteria in the filter. These authors consider that some variations in the density of coliform in distribution systems are caused by bacteria re-growth. Gale et al. (12), however, pointed out that the great variability of spore counts could be determined by spatial and temporal heterogeneity, which could be an important difficulty to the identification of an "ideal" surrogate for treatment plant performance.

Nieminski et al. (16) did not report the growth and spread of Bacillus subtilis or aerobic bacteria spores inside the filter media, but Rice et al. (19) described that the spores do not spread in several treatment processes. They considered that the simplicity of the method for determining endospores, the availability of indigenous populations of spores in typical waters, and their measurable presence in waters after filtration make them potentially useful tools for pilot studies and determination of filtering performance.

In this study, high concentrations of aerobic spores were found in the effluent of filtered water, presenting significant reverse-correlations only with Giardia in the USSF, suggesting either growth or detachment of these microorganisms from the filter during the filter run.

Adoption of turbidity as a surrogate is still a matter of concern. Although drinking water legislations, like the Brazilian (3), associate the low turbidity in the treated water with microbiological (or parasitological) safety, this issue lacks more conclusive statement, specially differentiating the several types of water treatment processes. In this field, although some authors $^{1}$ find no association between turbidity and protozoa concentration, others find significant associations $(15,16)$, usually investigating the effluent of rapid filters. The present investigation found no correlation between turbidity and the pathogenic protozoa in the effluent of slow sand filters. However, even though both the technical literature and the legislation consider turbidity a good performance indicator, it did not seems recommendable to use just this parameter for treated water quality control. In addition, the fragile response of turbidimeters for values below $0.1 \mathrm{uT}$ is an important issue here, remembering that Cryptosporidium outbreaks have been occurring with treated water with turbidity lower than this value.

As a monitoring alternative, Swertfeger et al. (23) consider that particle count and turbidity are more suitable to be used as real-time monitors - showing when the treatment may be compromised or whether immediate adjustments are necessary - than to determine process removal capacities.

This study shows that, in slow sand filters, efficient bacterial removal could indicate suitable protozoa removal, and that the mechanisms prevailing might be a combination of biological (total coliforms and E. coli) and physical (anaerobic spores) processes.

These results support the recommendation that the research for an indicator for Cryptosporidium and Giardia in drinking water treatment needs to be continuous. Although coliforms and $E$. coli do not present the appropriate physiological profile for an "ideal" indicator, they are still good references for drinking water microbiological quality, specifically for slow sand filtration. This and other studies have shown good correlations between these traditional indicators and protozoa. It is also reasonable to develop a discussion on the research of using anaerobic spores as a routine indicator.

Regarding the control of Cryptosporidium outbreaks, the expectation that a single indicator will satisfy all purposes is unreal. It may be more useful to know the advantages and disadvantages of several indicators, and use them appropriately.

\section{ACKNOWLEDGMENT}

The authors would like to acknowledge the financial support of the FUNASA, through the VIGISUS Project, and concession of scholarships by the CNPq.

\section{RESUMO}

\section{Associação entre a concentração de protozoários e indicadores substitutos em efluentes de filtros lentos de areia para o tratamento de água}

Atualmente, um grande desafio para a produção de água de elevado padrão de qualidade é o monitoramento de patogênicos, como Giardia, Cryptosporidium e vírus entéricos. Devido a limitações nos métodos analíticos para a detecção de patogênicos na água, a pesquisa de indicadores substitutos é um tema atual. Em vista desses aspectos, foi realizado um estudo em escala piloto para a avaliação da associação entre indicadores microbiológicos e físicos e a presença de Giardia spp e Cryptosporidium sp no efluente de filtros lentos de areia de escoamentos ascendente e descendente. Os resultados mostraram que uma remoção bacteriana eficiente pode indicar adequada remoção de protozoários. Embora coliformes e 
Escherichia coli não apresentem o perfil fisiológico apropriado de um indicador "ideal", eles são ainda boas referências para a qualidade microbiológica da água, especificamente para a filtração lenta. Os resultados também chamam a atenção para o necessário aprofundamento de pesquisas sobre o uso de esporos anaeróbios como um indicador rotineiro. Quanto ao controle de surtos de Cryptosporidium, a expectativa de que um único indicador satisfará todos os objetivos não é realista. Seria mais útil conhecer as vantagens e desvantagens de diversos indicadores e utilizá-los apropriadamente de forma integrada.

Palavras chave: Cryptosporidium, Giardia, filtração lenta, tratamento de água, indicador microbiológico

\section{REFERENCES}

1. Aboytes, R.; Di Giovanni, G.D.; Abrams, F.A.; Rheinecker, C.; Mcelroy, W.; Shaw, N.; Lechevallier, M.W. Detection of infectious Cryptosporidium in filtered drinking water. J. Am. Water Works Assoc., 96: 88-98, 2004.

2. American Public Health Association / American Water Works Association / Water Environment Federation. (1998). In: Standard Methods for the Examination of Water and Wastewater, $20^{\text {th }}$ edition, Washington, DC, 1998.

3. BRASIL. (2004). Ministério da Saúde. Portaria MS no 518/2004. Estabelece os procedimentos e responsabilidades relativos ao controle e à vigilância da qualidade da água para consumo humano e seu padrão de potabilidade, e dá outras providências.

4. Bellamy, W.D.; Silverman, G.P.; Hendricks, D.W.; Logsdon, G.S. (1985). Removing Giardia cysts with slow sand filtration. J. Am. Water Works Assoc., 77: 52-60.

5. Bellamy, W.D.; Cleasby, J.L.; Logsdon, G.S.; Allen, M.J. (1993). Assessing treatment plant performance. J. Am. Water Works Assoc. Management \& Operations, p.34-38.

6. Clancy, J.L.; Gollnitz, W.D.; Tabib, Z. (1994). Commercial labs: how accurate are they? J. Am. Water Works Assoc., 86: 89-97.

7. Di Bernardo, L.; Brandão, C.C.S.; Heller, L. (1999). Tratamento de Águas de Abastecimento por Filtração em Múltiplas Etapas. (Ed.) Rio de Janeiro: PROSAB - Programa de Pesquisa em Saneamento Básico. ABES - Associação Brasileira de Engenharia Sanitária e Ambiental, 114p.

8. Elmund, G.K.; Allen, M.J.; Rice, E.W. (1999). Comparison of Escherichia coli, total coliform, and fecal coliform populations as indicators of wastewater treatment efficiency. Water Environ. Res., 71: 332-339.

9. Fout, G.S.; Schaefer III, F.W.; Messer, J.W.; Dahling, D.R.; Stetler, R.E. (1996). Membrane filtration method for C. perfringens. ICR Microbial Laboratory Manual, EPA 600/R -95/178, Cincinnati.
10. Fox, K.R.; Lytle, D.A. (1996). Milwaukee's crypto outbreak: investigation and recommendations. J. Am. Water Works Assoc., 88: 87-94.

11. Gale, P.; Pitchers, R.; Gray, P. (2002). The effect of drinking water treatment on the spatial heterogeneity of micro-organisms: implications for assessment of treatment efficiency and health risk. Water Res., 36: 1640-1648.

12. Gale, P.; Stanfield, G. (2000). Cryptosporidium during a simulated outbreak. J. Am. Water Works Assoc., 92: 105-116.

13. Hendricks, D.W.; Clunie, W.F.; Anderson, W.L.; Sturbaum, G.D.; Klein, D.A.; Champlin, T.; Krugens, P.; Hancock, C.M.; Hirsh, J.; Mccourt, B.; Wendling, P.M.; Nordby, G. (1998). Biological particle surrogates for filtration performance evaluation. AWWARF Research Project Report, AWWARF, Denver.

14. Hendricks, D.W.; Clunie, W.F.; Sturbaum, G.D.; Klein, D.A.; Champlin, T.; Krugens, P.; Hirsh, J.; Mccourt, B.; Nordby, G.; Sobsey, M.D.; Hunt, J.; Allen, M.J. (2005). Filtration removals of microorganisms and particles. J. Environ. Eng. ASCE, 131: 1621-1632.

15. Hsu, B.-M.; Yeh, H.-H. (2003). Removal of Giardia and Cryptosporidium in drinking water treatment: a pilot-scale study. Water Res., 37: 1111-1117.

16. Nieminski, E.C.; Bellamy, W.D.; Moss, L.R. (2000). Using surrogates to improve plant performance. J. Am. Water Works Assoc., 92: 67-78.

17. Payment, P.; Franco, E. (1993). Clostridium perfringens and somatic coliphages as indicators of the efficiency of drinking water treatment for viruses and protozoan cysts. Appl. Environ. Microbiol., 59: 24182424.

18. Rice, E.W.; Fox, K.R.; Miltner, R.J.; Lytle, D.A.; Johnson, C.H (1994). A microbiological surrogate for evaluating treatment efficiency. Proc. AWWA WQTC, San Francisco.

19. Rice, E.W.; Fox, K.R.; Miltner, R.J.; Lytle, D.A.; Johnson, C.H (1996). Evaluating plant performance with endospores. J. Am. Water Works Assoc., 88: 122-30.

20. Roefer, P.; Monscvitz, J.T.; Rexing, D.J. (1996). The Las Vegas cryptosporidiosis outbreak. J. Am. Water Works Assoc., 88: 95-106.

21. Solo-Gabriele, H.; Neumeister, S. (1996). US outbreaks of cryptosporidiosis. J. Am. Water Works Assoc., 88: 76-86.

22. Sprinthall, R.C. (1999). Basic Statistical Analysis. Addison-Wesley Publishing Company, Inc., Reading, Mass. 1982. Apud: ELMUND, G.K., ALLEN, M.J., RICE, E.W. Comparison of Escherichia coli, total coliform and fecal coliform populations as indicators of wastewater treatment efficiency. Water Environ. Res., 71: 332-339.

23. Swertfeger, J.; Metz, D.H.; Demarco, J.; Braghetta, A.; Jacangelo, J.G. (1999). Effect of filter media on cyst and oocyst removal. $J$. Am. Water Works Assoc., 91: 90-100.

24. Tillett, H.E.; Sellwood, J.; Lightfoot, N.F.; Boyd, P.; Eaton, S. (2001) Correlations between microbial parameters from water samples: expectations and reality. Water Sci. Technol., 43: 19-22.

25. Vesey, G.; Slade, J.S.; Byrne, M.; Shepherd, K.; Fricker, C.R. (1993). A new method for the concentration of Cryptosporidium oocysts from water. J. Appl. Bacteriol., 75: 82-86.

26. WORLD HEALTH ORGANIZATION. (2004). Guidelines for drinking water quality; Recommendations. 3ed. Geneva: WHO. Vol. 1. 494p. 